\title{
STRATEGI PENGEMBANGAN MUSEUM BALAPUTRADEWA UNTUK MENINGKATKAN PENDAPATAN PEMERINTAH KOTA PALEMBANG
}

\author{
${ }^{1}$ Andini Dwi Indah Lestari*, ${ }^{2}$ Ida Santika, ${ }^{3}$ Wanda Tarisa, ${ }^{4}$ Maya Panorama \\ 1,2,3,4 Program Studi Ekonomi Syariah, Fakultas Ekonomi dan Bisnis Islam \\ UIN Raden Fatah Palembang \\ Andinidi191@gmail.com
}

\begin{abstract}
Abstrak
Museum Balaputra dewa adalah salah satu Museum negeri yang ada Di provinsi Sumatra selatan yang dikelompokan kepada lima (5) pameran akbar serta menyimpan banyak sekali macam koleksi. Adapun yang menjadi Identifikasi masalah kurangnya sarana dalam mempromosikan Museum, kurangnya pemeliharaan serta supervisi Museum, kurangnya minat rakyat mengenal sejarah masa lampau, kurangnya penyediaan Cinderamata diMuseum. Penelitian ini bertujuan mengetahui bagaimana taktik Museum Balaputra dewa bisa dikembangkan supaya lebih maksimal dan hambatan-kendala apa saja yang dihadapi. strategi pengembangan objek museum Balaputra dewa dalam upaya menaikkan pendapatan kota Palembang Di sector pariwisata pasca pandemi. Pandemi covid-19 sangat berdampak pada pendapatan kota Palembang sebab adanya restriksi sosial bersiklus besar dan ditutupnya akses keluar masuk antar kota, hal ini mengakibatkan penurunan pendapatan kota Palembang Di sector pariwisata. cara lain strategi yang dipergunakan ialah strategi yang meminimalkan kelemahaan (weaknesses) untuk memanfaatkan peluang (Opportunities) itu wajib dimanfaatkan buat meminimalkan kelemahan yang dimiliki dan dipergunakan untuk mengurangi ancaman eksternal. strategi tersebut sebagai jawaban penelitian untuk mengatasi konflik yang ada pada Museum Balaputra dewa sehingga pengembangan di Museum bisa diterapkan menggunakan optimal. Kata kunci: Museum Edukasi, Manajemen strategi, Pariwisata
\end{abstract}

\begin{abstract}
Balaputra Dewa Museum is one of the state museums in the province of South Sumatra which is grouped into 5 (five) large exhibitions and stores various collections. As for the identification of the problem of the lack of facilities in promoting the Museum, the lack of maintenance and supervision of the Museum, the lack of public interest in knowing past history, the lack of providing souvenirs at the Museum. This study aims to find out how the strategy of Balaputra Dewa Museum can be developed so that it is more optimal and what obstacles are faced. The strategy for developing the Balaputra Dewa museum object in an effort to increase the income of the city of Palembang in the post-pandemic tourism sector. The COVID-19 pandemic has greatly impacted the income of the city of Palembang due to large periodic social restrictions and the closure of access in and out between cities, this has caused a decline in the city of Palembang's income in the tourism sector. The alternative strategy used is a strategy that minimizes the weaknesses (weaknesses) to take advantage of the opportunities (Opportunities) that must be utilized to minimize the weaknesses they have and are used to reduce external threats. This strategy is the answer to research to overcome the problems contained in the Balaputra Dewa Museum so that the development at the Museum can be implemented optimally.

Keyword: Educational Museum, Strategic Management, Tourism
\end{abstract}

\section{PENDAHULUAN}

Sektor pariwisata adalah industry terbesar dan terkuat dalam pembiayaan ekonomi dunia during era globalisasi. Sektor pariwisata akan menjadi pendorong perekonomian global di abad ke-21, dan salah satu industri yang mengglobal. Sejalan dengan Pendit (1990), 
pariwisata mampu menghasilkan pertumbuhan ekonomi, karena dapat menyediakan lapangan kerja, menstimulasi berbagai sektor produksi, serta memberikan kontribusi secara langsung bagi kemajuan-kemajuan dalam usaha-usaha pembuatan dan perbaikan pelabuhan, jalan raya, pengangkutan serta mendorong pelaksanaan program kebersihan dan kesehatan, proyek sarana budaya, pelestarian lingkungan hidup dan sebagainya yang dapat memberikan keuntungan dan kesenangan baik kepada masyarakat setempat maupaun wisatawan dari luar. Pemerintah terus berusaha untuk berbagi kepariwisataan sejak 1978. Untuk menaikkan penerimaan devisa, memperluas lapangan kerja, dengan memperkenalkan kebudayaan, pariwisata harus ditingkatkan dan diperluas. (TAP Majelis Permusyawaratan Rakyat No. IV/MPR/1978) TAP Majelis Permus Pelatihan dan pengembangan pariwisata akan dilakukan dengan tetap memperhatikan kebudayaan dan kepribadian nasional. pelatihan dan pengembangan pariwisata dilakukan dengan tetap memperhatikan terpeliharanya kebudayaan serta kepribadian nasional. untuk itu perlu diambil langkah-langkah serta pengaturan-pengaturan yang lebih terarah sesuai kebijaksanaan yang terpadu, diantaranya bidang promosi, penyediaan fasilitas serta mutu \& pelayanan kelancaran.

Pengembangan pariwisata yang sudah dilakukan baik oleh pemerintah maupun partikelir telah menaikkan jumlah kedatangan wisatawan berasal suatu wilayah ke wilayah lain. Kunjungan wisatawan akan merangsang hubungan sosial menggunakan penduduk pada kurang lebih kawasan wisata dan merangsang tanggapan warga sekitarnya sesuai dengan kemampuan mereka dalam menyesuaikan diri baik dalam bidang perekonomian, kemasyarakatan juga kebudayaan mereka.

Museum adalah wadah untuk menyimpan, memelihara, melindungi, dan menggunakan barang bukti budaya manusia, alam, dan lingkungan untuk mendukung upaya perlindungan dan pelestarian kekayaan budaya negara. Keberadaan museum Indonesia sendiri belum dapat dikatakan sebagai tujuan kunjungan yang dapat menghasilkan devisa dan ketergantungan pada museum di negara maju..(Pemerintah Republik Indonesia angka 66 tahun 2015). Bukan hanya pembangunan fisik yang harus ditata ulang, namun sumber daya manusia juga harus ditingkatkan. Selain itu, pembangunan museum tidak hanya menjadi tanggung jawab pemerintah saja, tetapi juga tanggung jawab semua pihak.

Selama manajemen yang dilakukan tidak profesional, konstruksi fisiknya tidak nyaman, dan informasi yang ada di museum tidak disajikan dengan benar, selama ini berbagai museum di Indonesia tidak bisa dijadikan tempat untuk dikunjungi. Namun pada tahun 2019 sektor pariwisata mengalami kesulitan yang sangat berdampak pada semua aspek kehidupan hal ini dikarenakan adanya virus Covid19. Virus covid-19 ini juga menyerang perekonomian di dunia dengan banyak permasalahan karena efek berantai yang ditimbulkannya. Melemahnya sektor pariwisata di indonesia juga mulai dirasakan bahkan sebelum adanya himbauan jaga jarak dan beraktivitas di rumah saja di awal maret 2020 disertai dengan penemuan pasien positif corona pertama kali. Hal ini menyebabkan orang semakin takut untuk berpergian dan negara diisolasi. Sektor pariwisata di Sumatera Selatan juga menjadi salah satu provinsi yang mendapat efek dari penyebaran covid-19 ini.

Salah satu tempat objek Pariwisata di Provinsi Sumatera Selatan yang sangat berpengaruh terutama di kota palembang ialah museum Nasional Balaputradewa yang berada pada Jalan Srijaya No 288 KM 5.5, Alang Alang Lebar Kota Palembang Provinsi Sumatera Selatan. Museum ini termasuk sebagai objek wisata mengantongi potensi teknologi (IPTEK). Balaputeradewa, Museum Nasional Sumatera Selatan, melestarikan berbagai koleksi yang terdiri dalam 10 kategori, yaitu sejarah atau history (cerita), etnografi, 


\section{Sibcitie gourral}

Jurnal Ilmiah Bidang Sosial, Thonomi, Budaya, Tekvologi, dan Pendidikan

ekologi, keramik, indra teknologi modern, seni rupa (berupa patung), flora dan fauna. (Biologi) Dan geologi, rumah linmas dan rumah Ulu Ali. Dengan virus Covid-19, itu berdampak pada Museum Balaputra Dewa sendiri hal ini dapat dilihat dari pengunjung yang selalu mengalami penurunan dari tahun ke tahun. Museum Balaputra Dewa sendiri merupakan salah satu sektor pariwisata yang mampu meningkatkan perekonomian Provinsi Sumatera Selatan.

Rumusan Masalah pada penelitian ini ialah, taktik apa yang dapat dilakukan agar meningkatkan pengembangan Museum supaya meningkatkan pendapatan kota Palembang dalam sektor pariwisata.

Tujuan dari penelitian di sini adalah untuk memahami faktor penggalak dan penghalangnya di Museum Balaputeradewa untuk menaikkan pendapatan kota Palembang sektor pariwisata pasca pandemi.serta mengetahui strategi yg bisa dilakukan supaya meningkatkan dan mengembangkan Museum Balaputeradewa sebagai objek wisata.

\section{TINJAUAN PUSTAKA}

Menurut Spilane (1987), pariwisata adalah "perjalanan dari suatu tempat ke tempat lain, bersifat sementara, dilakukan perorangan maupun kelompok, sebagai usaha mencari keseimbangan atau keserasian dan kebahagiaan dengan lingkungan hidup dalam dimensi sosial, budaya, alam dan ilmu". Ditambah pula bahwa pariwisata terbagi atas beberapa jenis, yaitu: (1) pariwisata untuk menikmati perjalanan (pleasure tourism); (2) pariwisata untuk berekreasi (recreation tourism); (3) pariwisata untuk budaya (culture tourism); (4) pariwisata untuk olah raga (sport tourism); (5) pariwisata untuk urusan usaha dagang (business tourism); dan (6) pariwisata untuk berkonvensi (conventional tourism).

Menurut Joyosuharto (1995), pengembangan pariwisata memiliki tiga fungsi, yaitu: (1) memajukan perekonomian; (2) terpeliharanya kepribadian bangsa dan terpeliharanya fungsi dan kualitas lingkungan hidup; (3) menumbuhkan rasa cinta tanah air dan bangsa.

Fandeli (1995) berpendapat bahwa 'pariwisata adalah segala sesuatu yang berhubungan dengan pariwisata, termasuk pengoperasian fasilitas pariwisata dan perusahaan terkait di lapangan. Dijelaskan pula bahwa pariwisata adalah tindakan perjalanan dari suatu tempat ke tempat yang jauh dari rumah dengan tujuan bukan untuk mencari nafkah, tetapi untuk memulihkan kesegaran jasmani dan rohani agar dapat berdiri kembali. Sedangkan menurut Pendit (1990), pariwisata merupakan sektor kompleks yang juga mencakup industri klasik seperti kerajinan tangan dan cinderamata, serta perusahaan akomodasi, restoran dan transportasi.

Sejalan dengan Pendit (1990), pariwisata mampu menghasilkan pertumbuhan ekonomi, karena dapat menyediakan lapangan kerja, menstimulasi berbagai sektor produksi, serta memberikan kontribusi secara langsung bagi kemajuan-kemajuan dalam usaha-usaha pembuatan dan perbaikan pelabuhan, jalan raya, pengangkutan serta mendorong pelaksanaan program kebersihan dan kesehatan, proyek sarana budaya, pelestarian lingkungan hidup dan sebagainya yang dapat memberikan keuntungan dan kesenangan baik kepada masyarakat setempat maupaun wisatawan dari luar.

Selain subur akan alam, indonesia juga sangat kaya akan warisan budaya yang menjadi tapak jejak sejarah yang tertinggal, salah satu contohnya di Sumatera selatan yang memiliki history panjang keberadaanya. Provinsi yang beridiri sejak bertahun-tahun yang lampau yang dikenal dengan nama Bumi Sriwijaya ini yakni lokasi berdirinya sebuah kerajaan Maritim termasyhur di nusantara bernama Kerajaan Sriwijaya. Sebagai salah satu 
Provinsi yang memiliki history panjang, Sumatera Selatan tentu memiliki bermacam-macam benda peningalan bersejarah. Untuk mengurus dan melestarikannya, Dinas Kebudayaan dan Pariwisata Provinsi Sumatera Selatan membuat Museum Balaputeradewa di jalan Srijaya, Palembang. Museum yang memilki luas lahan sekitar $23.565 \mathrm{~m} 2$ (Pemerintahan Provinsi Sumatera Selatan,2009:12)

Museum merupakan sarana luar biasa untuk merawat budaya indonesia dan memupuk rasa nasionalisme. Salah satu museum yang ada di kota Palembang yaitu museum Balaputradewa, museum ini ialah salah satu museum bersejarah Sumatera Selatan yang menaungi lebih dari 3000 koleksi sejarah. Mulai dari koleksi prasejarah, jaman kerajaan Sriwijaya, sampai perang kemerdekaan (Ery dkk, 2010:3).

Yenny mengungkapkan dalam bukunya yang berjudul Museum Balaputradewa ia menjelaskan bahwa : Daerah Sumatera Selatan banyak mempunyai berbagai unsur budaya. Keanekaragaman itu menciptakan berbagai bentuk, jenis dan unsur serta corak seni budaya yang merupakan pencerminan segala sesuatu yang menyangkut aktivitas kehidupan masingmasing kelompok. Sejalan dengan itu, "Museum Negeri Provinsi Sumatera Selatan Balaputra Dewa, sesuai dengan tugas dan fungsinya juga aktif memikul beban dalam upaya memperkokoh ketahanan nasional antara lain dengan mengumpulkan, merawat dan memamerkan sekiaan yang dimaksud ialah rumah Tradisional yang bisa dikenal dengan rumah Limas atau Rumah Bari Palembang (Yenny, 1993:1).

Dari dua pikiran di atas, dapat disimpulkan bahwa Sumatera ialah pulau yang menarik bagi manca negara karena iletaknya iyang istrategis idan isumber idaya ialam iyang isangat idiminati idalam iperdagangan iinternasional.

Pelestarian kebudayaan pada dasarnya bukanlah semata-mata menjadi kepentingan dan tanggung jawab pemerintah, akan tetapi juga kewajiban semua lapisan masyrakat. Keikutsertaan masyarakat serta para anggota atau pelaku seni sangat dibutuhkan dalam usaha pelestarian kebudayaan. Pemerintah pun perlu menganjurkan kebebasan dan pengawasan kepada masyarakat dalam pengembangan kebudayaaan yang dipunyai oleh masyarakat. Beberapa hal yang dapat dilakukan diantaranya yakni melaksanakan pelestarian kebudayaan, pendataan, interverstasi, dan pendokumentasian beragam seni yang terdapat di setiap daerah.

Adanya tinjauan dari berbagai pihak perihal pelestarian khususnya kesenian tradisioanl, diharapkan dapat menjadikan unsur kebudayaan kian tumbuh, berkesinambungan bahkan dapat memberi corak terhadap kebudayaan bangsa Indonesia. Tinjauan dari berbagai aspek terkait dengan pelestarian kebudayaan sesuai dengan apa yag dikemukakan oleh Presiden Soeharto yakni secara sadar dunia mengalami berbagai perubahan dan bangsa Indonesia boleh jadi tidak menghindarinya. Sebab katena itu, kita sebagai masyarakat harus tetap berusaha melestarikan kebudayaan yang bersumber pada kebudayaan yang terdapat di Pelosok Indonesia salah satunya di Sumatera Selatan (Yoeti, 1985:51-52).

Tempat akumulasi bukti-bukti sejarah ini yakni Museum. Menurut Kamus Besar Bahasa Indonesia Pusat Bahasa Museum merupakan "gedung yang digunakan sebagai tempat untuk pameran tetap benda-benda yang patut menadapat perhatian umum, seperti peninggalan sejarah, seni, ilmu dan tempat menyimpan benda kuno (Depdiknas, 2008: 942). Selanjutnya menurut Handayani (2010:13) Museum adalah lembaga yang di peruntukkan bagi masyarakat umum yang berfungsi mengumpulkan dan merawat serta melestarikan warisan budaya masyarakat untuk tujuan studi, penelitian dan hiburan”. Dari dua penjelasan 


\section{Sibcitie gourral}

Jurnal Ilmiah Bidang Sosial, Thonomi, Budaya, Tekuologi, dan Pendidikan

tersebut, maka penulis dapat menarik kesimpulan kiranya Museum ialah tempat untuk menaungi benda-benda peninggalan sejarah yang bertujuan mengetahui keberadaan situs sejarah melalui benda-benda arkeolog yang terdapat dalam Museum.

Menurut definisi yang diajuakan oleh International Concil Of Museum (ICOM) pasal 3 dan 4 dam Mardiana berbunyi: Museum adalah sebuah lembaga tetap, tiadak mencari keuntungan, melayani masyarakat dan perkembangannya, terbuka untuk umum, yang mengumpulkan dan memelihara, meneliti, memamerkan barang-barang pembuktian dan lingkungannya untuk tujuan studi, pendidikan dan rekreasi. Museum merupakan lembaga pelestarian yang terpumpu pada kegiatan penelitian dan pengembangan warisan budaya. Sehingga museum juga memiliki tugas untuk melaksanakan pengumpulan perawatan, pengawetan, penyajian, penerbitan serta memberikan bimbingan tentang benda-benda yang mempunyai nilai budaya dan ilmiah yang bersifat regional (Mardiana, 2006:5).

Koleksi di Museum Balaputra Dewa di bagi menjadi 10 macam kategori yaitu historiografi atau historika (cerita-cerita), etnografi, feologi, keramik, alat-alat teknologi modern, seni rupa (berupa ukiran), flora fauna (biologika) dan geologi serta terdapat rumah limas juga rumah Ulu Ali. Koleksi-koleksi di Museum Balaputra Dewa ditempatkan pada 3 buah ruang pameran yang dikelompokkan menjadi 3 buah ruang pameran yang dikelompokkan menjadi ruang prasejarah, kesultanan Palembang Darussalam dan masa perang Kemerdekaan serta tambahan Rumah Limas (rumah/bangunan khas palembang). Di Museum Balaputra Dewa sekarang terdapat ruang khusus pertukaran budaya anatara kebudayaan kesultanan Malaka (Malaysia) dan Palembang (Indonesia). Ruang pamer Galeri kebudayaan Malaka ini baru di buka sekitar tahun 2011 saat Sultan Malaka berkunjung ke Palembang karena adanya keteriakatan batin dan budaya antara masyarakat Malaka dan Palembang (Pemerintah Provinsi Sumatera Selatan, 2009:2)

\section{METODE PENELITIAN}

Rancangan penelitian ini bersifat naratif kualitatif. Jenis penelitian naratif kualitatif yaitu suatu penelitian yang menghasilkan data secara deskriptif kualitatif adalah salah satu asal jenis penelitian yang termasuk dalam jenis penelitian kualitatif yang berupa keterangan, keadaan, kenyataan secara verbal maupun tertulis dari setiap prilaku orang yang ditinjau penelitian ini sendiri tidak mengadakan perhitungan. Data yang dikumpulkan bukan angkaangka melainkan berupa gambar dan istilah-istilah. semua yang dikumpulkan akan menjadi sebuah kunci terhadap apa yang telah diteliti. dengan demikian laporan ini akan berisi kutipan-kutipan buat menyampaikan laporan yang berupa ilustrasi penyajian.

\section{PEMBAHASAN}

Kota Palembang merupakan kota tertua di Indonesia, dengan usia 1382 tahun jika dipandang sesuai Prasasti Kedukan Bukit, warisan asal kerajaan Sriwijaya. sentra pemerintahan Kerajaan Sriwijaya merupakan Kota Palembang di zaman sekarang ini. berdasarkan Ismail (2012), Kota Palembang memiliki poly nilai jual pada global pariwisata. aneka macam macam destinasi wisata yang ditawarkan sangat berakar pada sejarah; mulai dari peninggalan seni, budaya, kawasan bersejarah, serta wisata makanan yang relatif populer dikalangan rakyat Indonesia maupun mancanegara.

Museum Negeri Sumatera Selatan Balaputera dewa menyimpan aneka macam koleksi yang dibagi menjadi 10 macam kategori yaitu histografi atau historika (cerita-cerita), etnografi, feologi, keramik, alat-indera teknologi terkini, seni rupa (berupa ukiran), flora- 
fauna (biologika) dan geologi serta ada rumah limas pula rumah ulu ali. Koleksikoleksi di Museum Balaputra dewa ditempatkan pada 5 (5) tata pameran akbar 1. Masa Prasejarah Sumatera Selatan, 2. Masa Sriwijaya, Kesultanan Palembang serta Masa Kolonial, 3. Kerajinan Tradisional Sumatera Selatan, 4. Bangsa Arca, 5. Galeri Malaka.

Keberadaan museum Indonesia sendiri, seperti halnya museum di negara maju, tidak dapat dijadikan sebagai target kunjungan penghasil devisa. Tidak hanya kita perlu menata ulang perkembangan fisik kita, kita juga perlu meningkatkan bakat kita. Namun pada tahun 2019, sektor pariwisata menghadapi tantangan yang dapat berdampak besar pada setiap aspek kehidupan. Hal ini dikarenakan adanya virus Covid19.

Perlambatan sektor pariwisata Indonesia semakin terasa pada awal Maret 2020, bahkan sebelum himbauan social distance dan home activity dengan ditemukannya pasien positif corona pertama. Hal ini membuat orang lebih takut bepergian. Industri pariwisata di Sumsel juga menjadi salah satu negara yang terdampak wabah COVID 19, terbukti dengan menurunnya pengunjung, Museum Baraptradewa sendiri terdampak parah akibat virus Covid 19. Untuk meningkatkan pembangunan Museum Negeri Barapteradewa di Sumatera Selatan untuk meningkatkan perekonomian sektor pariwisata dan meningkatkan pendapatan kota Palembang, untuk meningkatkan pendapatan kota Palembang di sektor pariwisata pascapandemi Perlu sebuah strategi praktis. Penyusunan museum tidak sematamata menjadi tanggung jawab pemerintah saja, namun juga tanggung jawab semua pihak yang ada termasuk masyarakat. Selama ini berbagai museum di Indonesia tidak bisa dikunjungi kecuali pengelolaannya profesional, struktur fisiknya tidak nyaman dan informasi tanggal museum disajikan dengan baik.

Sangat membanggakan kota Palembang di Sumatera Selatan, museum ini lebih beraneka ragam dari museum swasta dan museum negara lainnya, tetapi perlu memiliki strategi pengembangan dan inovasi / proses yang sebaik strategi dan inovasi pengembangan yang ada. Salah satu proses penerapan Museum Balaptradewa tidak terlihat atau dirasakan oleh masyarakat umum atau Museum Balaptradewa itu sendiri. Ini adalah masalah yang perlu diselesaikan. Untuk mengatasi berbagai permasalahan Museum Balaptradewa maka perlu dilakukan analisis strategi yang lebih baik dalam pengembangannya agar Museum Balaptradewa lebih baik lagi dan menarik pengunjung.Museum Negeri Sumatera Selatan Balaputradewa ini termasuk kedalam objek wisata yang mempunyai potensi ilmu pengetahuan dan teknologi (IPTEK). Situasi ini menjelaskan mengapa Museum tidak cuma sebagai objek wisata tetapi juga tempat belajar. Melalui perkembangan museum yang semakin positif maka dapat mampu memberikan lapangan pekerjaan kepada masyarakat.

Pengembangan pariwisata yang telah dilakukan baik oleh pemerintah maupun swasta untuk meningkatkan jumlah kedatangan wisatawan dari suatu daerah ke daerah lain. Kunjungan wisatawan akan merangsang interaksi sosial dengan penduduk di sekitar tempat wisata dan merangsang tanggapan masyarakat sekitarnya sesuai dengan kemampuan mereka dalam beradaptasi baik di bidang perekonomian, kemasyarakatan maupun kebudayaan.

Sudah seharusnya Museum dirawat dan dikelola dengan baik, hal ini berguna buat keberlangsungan museum itu sendiri. Perawatan dan pengelolaan museum ini tentunya dapat mensugesti minat masyarakat buat melakukan kunjungan museum. Semakin baik perawatan dan pengelolaannya tentu meningkat pula hal ini untuk mempengaruhi minat warga untuk melakukan kunjungan hal ini juga berlaku sebaliknya.

Pengunjung merupakan suatu yang sangat krusial bagi museum. Pengunjung artinya setiap orang yang tiba ke suatu tempat dengan memiliki maksud serta tujuan eksklusif 


\section{Sibcatie gourenal}

Jurnal Ilmiah Bidang Sosial, Thonomi, Budaya, Tekvologi, dan Pendidikan

kecuali seseorang yang melakukan pekerjaan dengan mendapatkan upah. Pengunjung ini bisa berupa orang yang bertujuan melakukan rekreasi, penelitian juga hal lainnya. Intinya suatu objek wisata bisa dikatakan mengalami perkembangan apabila kunjungan wisatawan Mancanegara serta jua Nusantara mengalami kenaikan ataupun dalam keadaan stabil.

Peningkatan kuantitas wisatawan akan lebih positif bila diikuti oleh peningkatan kualitas wisatawan itu sendiri, apabila peningkatan kuantitas tidak menyebabkan peningkatan kualitas, yang terjadi Museum Balaputradewa tidak jauh berbeda, hanya tempat hiburan seperti tempat lainnya. Berapun banyaknya wisatawan yang datang ke Museum Balaputradewa tidak akan berarti apabila mereka tidak memahami apa arti dan manfaat yang ada pada Museum dan benda koleksi yang ada. Dikarenakan kebanyakkan wisatawan yang datang cuma untuk berwisata saja. Maka dari itu pemandu di Museum Balaputra Dewa membutuhkan pendidikan dan pelatihan yang baik supaya bisa memberitahu sejarah dan isi Museum Balaputradewa dengan umum memberikan ilmu yang berharga untuk wisatawan yang datang.

Lingkungan internal dan eksternal merupakan tindakan penting dalam mengkaji strategi pengembangan yang ada Museum Balaputradewa dengan sekitarnya, kita juga bisa mengkaji kekurangan apa yang harus dimusnahkan dan apa yang menghalangi kontretisasi strategi saat ini supaya tidak mengacau lingkungan. kehadiran/keunggulan Museum Balaputradewa dan ancaman dari pesaing sehingga dapat diatasi secara cepat. Strategi peningkatan yang ada di Museum Balaputradewa diharapkan bisa memusatkan pada pengembangan yang bermanfaat untuk kemajuan Museum Balaputradewa itu sendiri. Mengembangkan strategi amat signifikan karena strategi merupakan kerangka dasar. Faktor luar terdiri dari harapan dan risiko, sementara itu faktor dari dalam terdiri dari kekuatan dan kelemahan.

Museum Negeri Sumatera Selatan Balputradewa susah berkembang dengan signifikan dikarenakan program pengembangan yang ada belum maksimal. dan tidak adanya dana pemerintah. Pendanaan telah didistribusikan kembali di banyak kegiatan di Museum, salah satunya adalah promosi terbatas ini. Maka dari itu dengan dana yang sangat sedikit ini memerlukan kerja keras berupaya meningkatkan kesadaran masyarakat supaya berminat berkunjung ke Museum ini.

Komunikasi pemasaran menawan bagian signifikan dari pemasaran. Menurut pendapat Kotler dan Keller (2012:498), komunikasi pemasaran merupakan suatu alat yang dipergunakan lembaga atau organisasi dalam menginformasikan, merayu, dan mengingatkan konsumen baik secara verbal maupun secara non verbal mengenai sesuatu yang mereka jual. Komunikasi pemasaran amat penting dilaksanakan organisasi. Tanpa adanya komunikasi pemasaran yang dilakukan maka para calon konsumen tidak akan mengenal apa yang mereka jual tersebut.

Menurut Burhan Bungin (2015:59) target dari komunikasi pemsaran tidak menjual apa yang organisasi atau forum miliki, akan tetapi targetnya adalah pengetahuan pelanggan berhubungan dengan sesuatu yang dimiliki organisasi atau forum tersebut sehingga calon pelanggan bisa mengenal dan mengerti hal tersebut. Dengan para calon pelanggan mengenal \& paham hal itu tentu saja bisa menarik keinginan para calon pelanggan tadi untuk memakai juga membangun dan menciptakan sebuah merk awarness pada mata para konsumen. Oleh karenanya pada melaksanakan komunikasi pemasaran wajib dilakukan secara cermat $\&$ sempurna buat menerima output yg maksimal. Ini memperlihatkan bahwa komunikasi pemasaran sangat diharapkan \& krusial demi keberlangsungan suatu organisasi atau 
lembaga. Salah satu forum yang pula melakukan komunikasi pemasaran yaitu Museum Balaputra Dewa.

Masalah selanjutnya ialah lokasi, seringkali menjadi faktor penting yang mempengaruhi jumlah pengunjung suatu objek wisata. Lokasi tempat wisata yang dekat dengan pusat keramaian tentunya akan mempermudah menarik wisatawan untuk berkunjung ke tempat wisata ini dibandingkan dengan lokasi tempat wisata di Alang-Alang Lebar Sukarame kota Palembang, lokasi ini hanya di dorong oleh kendaraan pribadi. kendaraan karena letak bangunan Museum Balaputra Dewa, menjorok dari sisi jalan raya, sehingga sedikit pengunjung yang mengetahui bahwa hanya ada sekolah, dan di depan Museum terdapat PLN, PT. Gardu Induk PLN (Persero).

Selain pelayan yang disediakan oleh pihak Museum, ternyata sarana yang menyertainya merupakan nilai positif dan berdampak signifikan pada tingkat suasana yang akan tercipta. Memperbaiki sarana yang ada, seperti panah arah dan masukan, lapangan parkir, kedai museum, perpustakaan, gerai suvenir, tempat istirahat misalnya taman, taman di dalam museum, toilet, meningkatkan keamanan berupa cctv dan security, harus lebih ditingkatkan lagi.

Strategi selanjutnya yaitu semua organisasi atau karyawan yang ada harus melakukan promosi melalui media masa internet, televisi, serta mempersiapakan berita berupa data Museum sebagai media iklan memberikan suatu arahan agar pandangan masyarakat sadar akan pentingnya museum dan membangun sosialisasi cinta Museum serta mengembangkan inovasi wisata bersejarah dan budaya. Struktur organisasi yang ada pada meseum memang sudah sangat nyata antara yang satu dengan yang lain masing-masing bagian melaksanakan tugas masing-masing sesuai tugas utama dan fungsi yang diharapkan. Namun pelaksaan tersebut belum efektif dikarenakan setiap hari wisatawan yang datang terbilang sedikit. Kebanyakan yang bertugas untuk mengguide melihat disana sepi maka mereka lebih memilih untuk tetap berada di dalam ruangan.

Salah satu kelemahan yang harus langsung di tangani oleh pihak Museum adalah memberikan motivasi kepada masyarakat agar turut berpartisipasi aktif dalam menyediakan cindera mata supaya menambah penghasilan. Cinderamata yang dapat diberikan yaitu apabila ada suatu acara serta kegiatan alangkah baiknya jika cindera mata dapat dijual kepada wisatawan karena suatu kesenangan tersendiri bagi wisatawan apabila pulang membawa oleh-oleh dari tempat yang dikunjungi. Cindera mata bisa dapat dijadikan salah satu media promosi bagi Museum. Serta mengoptimalkan potensi destinasi Museum agar mampum bersaing dengan wisata lain dan bisa membangkitkan perekonomian yang ada di kota Palembang.

Oleh karenanya buat meneruskan kehadirannya ditengah warga, museum wajib melaksanakan suatu hal yg bisa menarik minat para calon wisatawan. Pengunjung pada hal ini adalah asal daya insan yg krusial bagi museum, jika tidak ada wisatawan museum hanya adalah sebuah bangunan penyimpanan memberi pengetahuan pada warga tentang apa yg terdapat pada Museum Balaputradewa tadi tentunya dibutuhkan suatu aktivitas mempromosikan. Promosi dan iklan yang dapat dilakukam oleh pihak museum yaitu dengan melakukan kegiatan komunikasi pemasaran agar halnya dapat menarik keinginan para calon wisatawan untuk melakukan kunjungan.

Berikut adalah klasifikasi ketangguhan dan kekurangan Museum Balaputradewa Sumatera Selatan menjadi ancaman terkait lingkungan internal, peluang dan lingkungan luar. 


\section{Sibatile Jocurral}

Jurnal Ilmiah Bidang Sosial, Ekonomi, Budaya, Tekuologi, dan Pendidikan

\section{Analisis lingkungan dalam (internal)}

Museum Negeri Balaputeradewa sukar dikembangkan dikarenakan program periklanan yang ada tidak optimal. dan kurang persediaan pemerintah. Uang tersebut kembali dipecah buat banyak kegiatan di museum, contohnya seperti promosi terbatas. Sehingga dibutuhkan banyak usaha untuk menarik perhatian masyarakat terhadap fakta bahwa orang ingin mengunjungi museum ini dengan biaya yang paling murah.

\section{Lokasi yang tidak esensial dan sepi serta jauh dari keramaian}

Museum Balaputradewa ini berada di Jalan Srijaya. Lokasi seringkali menjadi salah satu faktor signifikan dalam jumlah wisatawan suatu objek wisata. Lokasi objek wisata yang berada ditempat pusat keramaian tentunya sangat memudahkan untuk menarik pengunjung dibandingkan dengan Alang Alang Lebar Sukarami di Palembang, tempat objek wisata tersebut berada. Di sini gedung menjorok dari pinggir jalan raya, sehingga banyak pengunjung yang tidak tahu.

\section{Tersedia Sarana Pendukung}

Selain pelayan-pelayan yang disediakan oleh pihak museum, terbukti bangunanbangunan penunjang tersebut memiliki nilai lebih dan amat mendorong tingkat roman yang hendak tercipta di lingkungan museum tersebut. Sarana pra sarana termasuk yaitu lahan parkir, kios museum, perpustakaan, gerai oleh-oleh, tempat rekreasi seperti taman di dalam museum, toilet umum yang tidak sepenuhnya terawat, sementara toilet staf di gedung utama yang kondisinya sangat baik dan terdokumentasi. Visual atau media, seperti kaset program, dan infrastruktur pendukung, seperti auditorium museum.

\section{Budaya Organisasi}

Museum Balaputra Dewa di bawah naungan Dinas Kebudayaan dan Pariwisata provinsi Memiliki struktur organisasi yang sangat jelas, dan masing-masing bagian menjalankan tanggung jawabnya sesuai dengan tugas pokok dan fungsi yang diharapkan. Namun, implementasinya dinilai tidak efektif karena jumlah pengunjung harian yang relatif sedikit. Pada umumnya, staf pemandu lebih memilih untuk tetap berada di dalam ruangan karena mereka memastikan tempat tersebut dalam keadaan tenang. Namun melihat struktur organisasi secara keseluruhan berjalan dengan baik karena setiap karyawan memiliki pekerjaan yang jelas dan terstruktur.

\section{Tidak terdapat petunjuk arah masuk}

Rambu-rambu perlu dipasang kembali seperti semula agar wisatawan tersesat atau perjalanan dilanjutkan. Untuk meningkatkan jumlah pengunjung museum maka perlu dilakukan peningkatan pelayanan dan peningkatan fasilitas yang ada. Penghapusan penanda jalan masuk sebelumnya, plang petunjuk arah jalan tersebut di copot atau di cabut oleh Satuan Pamong Praja (SatPol PP).

\section{Tiket Masuk (karcis) yang murah}

Tiket masuk Museum ini sangat terjangkau untuk semua orang, yang salah satu sumber penghasilan untuk Museum Balaputradewa berasal dari dana APBD dan pemasukan yang lain berasal dari penjualan tiket untuk masuk ke museum. Harga karcis relatif sangat murah, yaitu tiket untuk dewasa perorangnya Rp.2000, dan anak-anak perorangnya 
Rp.1000-sehingga kita tidak perlu menghabiskan banyak uang untuk menikmati tur museum dan menjelajahi bagian dalamnya Museum Balaputra Dewa.

\section{Pemasukan}

Semua kegiatan yang dilaksanakan di museum dilakukan dalam APBD, namun museum 2018 menerima dana lebih sedikit disbanding dengan tahun 2017 jika ditinjau dari museum kota lain. Museum Balaputradewa sangat tertinggal jauh lantas bagaimana aktivitas promosi dapat tercapai dengan baik.

\section{Museum miliki koleksi tentang history kegemilangan masa lampau di Sumatera Selatan}

Sumatera Selatan memiliki history panjang keberadaannya. Provinsi yang dikenal berabad-abad sebagai sriwijaya ini merupakan tempat berdirinya kerajaan paling terkenal di Nusantara yang bernama Kerajaan Sriwijaya. Pada abad ke-15, Kesultanan Palembang didirikan dan diperintah sebelum penjajahan Belanda datang ke bumi. Sri Vijaya adalah salah satu wilayah kepulauan di mana pemukiman yang berasal dari periode megalitik telah ditemukan.

\section{Mutu dan Kapasitas Cinderamata}

Kelemahan yang perlu dibenahi adalah oleh-oleh yang bisa dihadiahkan Museum Balaputradewa Saat ada acara serta kegiatan lebih baik jika pihak museum bisa menjual suvenir kepada pengunjung. Karena membawa pulang cinderamata dari tempat yang dikunjungi merupakan kebahagiaan tersendiri. Souvenir dapat digunakan sebagai media periklanan museum.

\section{Mempunyai kekuatan sebagai tempat analisis dan wisata edukatif}

Wisata edukatif Museum Balaputradewa dengan membantu wisatawan yang berkunjung belajar dari pengalaman mereka sendiri, mereka lebih memahami dan memahami bagaimana sejarah budaya kejayaan sebelumnya dibandingkan dengan membaca teori di buku pelajaran sekolah (hasil dari wawancara kepala Museum BalaputraDewa).

\section{PENUTUP}

\section{Kesimpulan}

Berdasarkan hasil pembahasan diatas maka kesimpulan yang dapat ditarik adalah Museum Balaputradewa mempunyai efektivitas yang masih dapat dikembangkan menjadi sangat unggul, namun kemampuan tersebut belum maksimal, maka dari itu Museum harus memanifestasikan strategi dengan memanfaatkan strategi yang meminimalkan kekurangan untuk memanfaatkan peluang. Sementara itu peluang harus dimanfaatkan untuk meminimalkan kekurangan yang dimiliki serta dipakai untuk mengurangi ancaman dari luar. Beberapa kelemahan tersebut yaitu tidak ada penah arah, lokasi tidak esensial, kuantitatif dan kualitatif barang cinderamata, dan biaya yang kurang.

Strategi yang dapat dilakukan untuk mengembang objek wisata museum balaputeradewa agar dapat meningkatkan pendapatan kota Palembang ialah dengan cara memperbanyak fasilitas semacam panah arah, wahana serta kotak tinjauan karena dari hal yang sekecil itu sangat berarti untuk membangun dan mengembangkan museum. Serta lebih memperbaiki pemeliharaan dan memberikan pengawasan security serta cctv maupun 


\section{Sibatile Jowrmal}

Jurnal Ilmiah Bidang Sosial, Ekonomi, Budaya, Tekuologi, dan Pendidikan

pegawai untuk ikut memandu wisatawan yang dating agar tidak terjadinya perusakan dan pencurian benda-benda koleksi yang ada di Museum. Menyampaikan sebuah arahan agarmerubah persepsi masyarakat supaya sadar bahwa pentingnya Museum sehingga terciptanya minat masyarakat untuk mengenal sejarah kejayaan pada masa lampau lebih meningkat lagi dan tidak tepengaruh budaya luar. Memotivasi masyarakat memberikan arahan agar turut berperan aktif dalam pengembangan Museum Balaputradewa dan alangkah baiknya jika museum turut menjual cinderamata yang ada disaat ada wisatawan yang datang sehingga bisa mendapatkan penghasilan tambahan dan membuat pengunjung bangga membawa pulang cinderamata dari tempat wisata. Serta melakukuan pengajuan usulan kegiatan kepada Pemerintah Provinsi Sumatera selatan melalui Dinas Kebudayaan dan Pariwisata agar lebih diperbanyak anggaran APBD supaya museum bisa sebanding dengan kegiatan yang dilaksanakan.

\section{DAFTAR PUSTAKA}

Bungin, Burhan. 2015. komunikasi pariwisata (tourism communication): Pemasaran dan Brand Destinasi. Jakarta: prenadamedia group

Depdiknas. 2008. Peraturan Pemerintah RI No.19 Tahun 2005 tentang Standar Nasional Pendidikan. Jakarta: Depdiknas.

Fandeli, Chafid, 1995. Potensi Obyek Wisata Alam. Dalam Chafid Fandeli (Ed) Dasar-Dasar Manajemen Kepariwisataan Alam. Yogyakarta : Liberty

Joyosuharto, Sunardi, 1995. Aspek Ketersediaan (Supply) dan Tututan Kebutuhan (Demand) Dalam Pariwisata.

Kotler, P. \& Keller, K.L. (2012), Manajemen Pemasaran Jilid I Edisi ke 12. Jakarta: Erlangga.

Mardiana. 2006. Hubungan Perilaku Dengan Status Gizi Balita di Puskesmas Tanjung Beringin Kecamatan Hinai. Skripsi. Fakultas Kesehatan Masyarakat Universitas Sumatera Utara. Sumatera Utara.

Peraturan pemerintah Republik Indonesia Nomor 66 tahun 2015 tentang Museum

Peraturan Pemerintah Prov. Sumatera Selatan No. 12 Tahun 2009 tentang Ruang Lingkup.

Pendit, Ny. S. 1990. Ilmu Pariwisata, Sebuah Pengantar Perdana, PT Pandnya Paramita, Jakarta

S.Saragih, Meriati,dkk. (2016). Buku panduan Museum negeri Balaputera Dewa Sumatera Selatan. Palembang.

Siagian,Sondang P. (2005). Manajemen Strategi. Jakarta: Bumi Aksara

Spillane, J. J. (1987). Ekonomi pariwisata: Sejarah dan prospeknya. Kanisus.

Wahyudi, Agustinus Sri. (1996). Manajemen Strategik, Pengantar Proses Berfikir Strategik. Jakarta: Binarupa Aksara

Yenni Salim. (2002). Kamus Bahasa Indonesia Kontemporer. Modern English. Jakarta: Press.Jakarta

Yoeti, Oka A. (1985). Pengantar Ilmu Pariwisata, Bandung: Angkasa 
